\title{
鉄筋コンクリート床スラブの歩行時振幅の推定法 A METHOD OF ESTIMATING AMPLITUDE OF VIBRATION OF REINFORCED CONCRETE FLOOR SLABS BY WALKERS
}

\author{
伊 藤 正 義*, 井野 智**, 杉野目 章***, 植 松 武是**** \\ Masayoshi ITO, Satoru INO, Akira SUGINOME and Takeyoshi UEMATSU
}

\begin{abstract}
The degree of human perception of vibration of floor slabs generally is estimated in terns of major vibration criteria, natural vibration period $T_{1}$ and amplitude $\delta$. As for $T_{1}$ we have already proposed regression equations for it as a function of long-time floor deflection, which were derived from systematic analyses of our so far accumulated field data; thus enabling direct and simple estimation of $T_{1}$ using long-time floor slab deflection obtainable by any standard method.

Currently, resulting from further analysis using the same data, a strong functional relation has proved to exist between those $T_{1}$ and $\delta$ caused by walkers. Accordingly, our last and present formulation combined may enable us to quantify human perception of floor vibration approximately by available vibration evaluation curves such as Meister's which use both of the said criteria.
\end{abstract}

Key words : reinforced concrete floor slab, vibratory perception, frequency, amplitude in walking, in-situ measured data, estimating equation

R C 床スラブ、振動感覚、振動数、歩行時振幅、調查デー夕、推定式

\section{1 、はじめに}

日本建築学会の鉄筋コンクリート（以下R C と略記す る）構造計算規準には、床スラブの使用性に係わる検討 項目として、付 11 と付 13 にそれそれ「床スラブの振 動」と「長期荷重下における変形とひび割れ」について の予測計算法が示されている ${ }^{1)}$ 。前者が主に弾性振動を 対象としているのに対し、後者はコンクリートのひび割 れと時間依存性を考慮したものになっており、両者が対 象とする適用範囲には大きな違いがある。先に筆者らは、 これらの間に整合性をもたせるため、コンクリートのひ び割れや時間依存性を考慮した R C 床構造の振動数を長 期たわみ予測值から推定する実用的な方法を提案した ${ }^{2) 。 ~}$ 振動に関する居住性能評価は、日常的な振動発生源に よる加振条件下の床応答波形の振動数、振幅、減衰定数 を照合することにより行われている3゙。

本論文では、前報 ${ }^{2}$ で用いた既往のデータを精査分析 して、床振動の振動数と振幅の間に強い関数関係がなり
立つことを示し、最も日常的な加振源である歩行を対象 として、コンクリートのひび割れやクリープ変形などを 伴う R C 床スラフ振動の変位振幅を簡便に推定する略算 式を導いた。

また、本研究で取り上げた調査建物の一つである R C 事務所における 148 枚の床スラブで計湘した歩行時の 振動記録と 5 人の被験者による段階的感覚評価の結果を 整理し、振動数と歩行時変位振幅のそれぞれについて統 計分析を行ない、振動感覚上問題となる限界値を見いた した。このような調査の累積により歩行時振動に対する 感覚限界曲線の作成が可能である。今後の参考に供する ため、振動感覚評価に関する本調查テータの分析の過程 を併せて報告する。

\section{2. 娭討対象床スラフの极要 2)4/5)}

本報では、大梁間が 1 パネルからなる $\mathrm{R} \mathrm{C}$ 床スラブの 実測テータを用いて以下の検討を行った。

$*$ 北海道工業大学工学部経営工学科 教授

** 北海道大学工学部情報図形科学講座 教授 - 工博

**** 室蘭工業大学工学部建設システム工学科 教授・工博

**** 北海道大学大学院工学研究科 大学院生.工修
Prof., Dept. of Industrial Engineering, Faculty of Engineering, Hokkaido Institute of Technology

Prof., Dept. of Computer and Graphic Science, Faculty of Engineering, Hokkaido Univ., Dr. Eng.

Prof., Dept. of Architecture and Civil Engineering, Faculty of Engineering, Muroran Institute of Technology, Dr. Eng.

Graduate Student, Graduate School of Engineering, Hokkaido Univ., M. Eng. 
調查建物は 6 件で、㛟討対象とした床スラブの構造諸 元と振動性状は文献 2 ) の表 1 および表 2 に揭げる通り である。

調查建物 $F$ (事務所) とG (小学校) の二つは床たわ み障害の程度が比較的軽微なものであるが、建物 D（病 院）とE（事務所）は床たわみ障害の程度がやや大きく、 また、建物 B（集合住宅）とC（事務所）についてはそ の障害の程度が特に甚たしく歩行時振幅も非常に大きく 飛び離れた状態のものである。

振動感賞評価に関する检討は、文献 4）に揭ける「あ る多層 R C 事務所建築の床構造についての総合的実態調

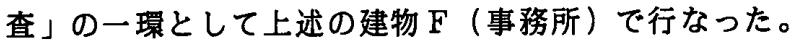
図 1 は同建物の基準陵梁伏図である。ここで取り上げた 床スラフは付表 1 に揭げる設計諸元をもつ平板 98 枚、 ドロップハンチ付き平板 50 枚である。スパンは $6.0 \mathrm{~m}$ $\times 6.8 \mathrm{~m}, 5.6 \mathrm{~m} \times 6.0 \mathrm{~m}$ の 2 種類で、スラフの組み込まれ る架構状䔮は内スパン、外スパン、隅スパンからなる全 部で 10 種類である。

\section{3. 歩行時变位振幅について}

\section{1 実測データの求め方}

検討対象を $\mathrm{R} \mathrm{C}$ 床スラブに生ずる歩行時の鉛直振動に 限定する。振動数および振幅は、時系列波形から直接求 める、いわゅるオーバーオールによる方法によった。

(1) 速度型換振器をスラブ中央に設置し、換振器を中心 とする半径約 $1 \mathrm{~m}$ の円周上を大人が普通の状態で歩行す るときのスラフ振動の変位応答を記録した。床スラフの
固有振動数が卓越する部分の波の数と時間の長さから振 動数を求めた。

また、歩行時の变位振幅は、歩行ステップの周期約 0 . 5 秒間隔で繰り返される時系列波形ことの最大全振幅の 1 $/ 2$ とし、2 周、約 25 歩分の平均値をとり実測データ とした。

（2）建物 Fにおける振動感覚評価に関する試験では、5 人の被験者と歩行者の距離、および換振器と歩行者の距 離がほほ等しくなるように、被験者と換振器をそれそれれ 後揭の図 8 のように配置し、各被験者および換振器から の至近距離が約 $0.75 \mathrm{~m}$ を通る直線歩行とした。

この場合の時系列波形からの読み取りは、前項円周歩 行とほぼ同じ平均振幅が得られるように、至近距離通過 時およびその前後 2 歩分を採用した。このようにして求 めた直線歩行と円周歩行の対芯は図 2 に示す通りである。

3.2 歩行時変位振幅のばらつき

調查期間が長期に及ぶ実測デー夕間のばらつきを極力 少なくするため、歩行者は本研究の振動計測を継続して きた井野が主に担当した。

同人による歩行時振動の変位振幅のばらつき、あるい は歩行者の異なる場合の振幅のばらつきを明らかにする ために追試験を実施したところ、表 1 に示すような結果 を得た。

表 1 によれば、井野個人の平均値に対する標準偏差の 割合 (変動係数) は27.5\%、最大または最小值はそれぞ れ平均値の約1.6、0.6倍である。また、他の男性 6 人、 女性 3 人のそれそれれの歩行時振動テータについては、変 位振幅の変動係数は $38.9 \sim 12.5 \%$ 、最大值は平均值の 1 .

付表 1 実験值から推定した主要床スラブの設計諸元
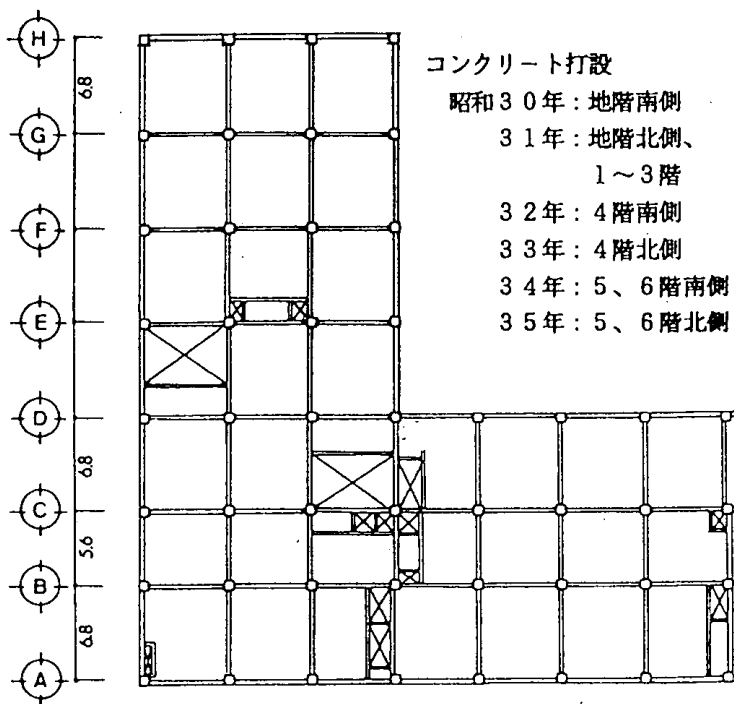

\begin{tabular}{c|c|c|c}
\hline \multirow{2}{*}{ 階 } & 種 類 & $\begin{array}{c}\text { 梁心スバン } \\
\mathrm{m} \\
\mathrm{L} \times \mathrm{L}\end{array}$ & $\begin{array}{c}\text { スラブ厚 } \\
\mathrm{mm} \\
\text { 端部 /中央 }\end{array}$ \\
\hline \multirow{2}{*}{$1 \sim 4$} & \multirow{2}{*}{ 平 板 } & $6.0 \times 6.8$ & 160 \\
\cline { 3 - 4 } & & $5.6 \times 6.0$ & 160 \\
\hline \multirow{2}{*}{5,6} & \multirow{2}{*}{ 変厚板 } & $6.0 \times 6.8$ & $230^{* 1} / 160$ \\
\cline { 3 - 4 } & & $5.6 \times 6.0$ & $230^{* 1} / 160$ \\
\hline
\end{tabular}

$* 1$ : 変厚板端部の厚肉幅 $600 \mathrm{~mm}$

34 年: $5 、 6$ 穈南僋

35 年: $5 、 6$ 整北制

(D).

c)

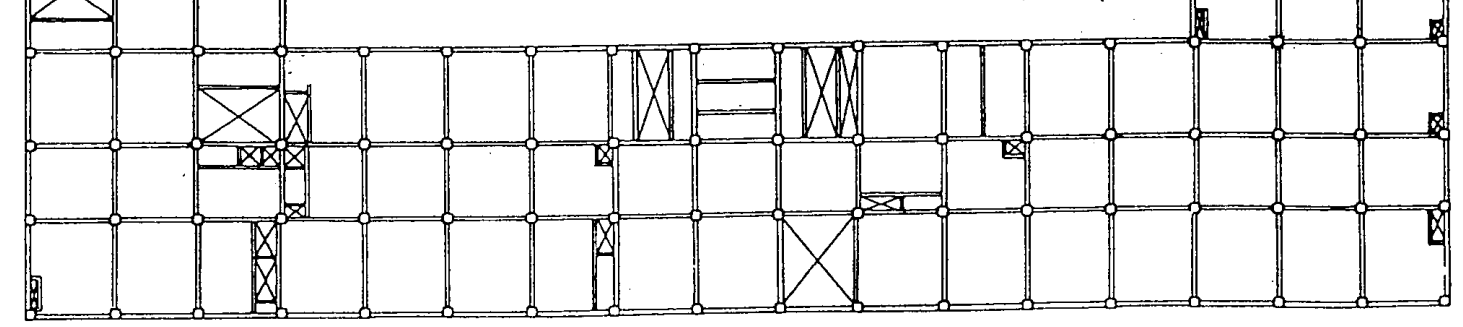

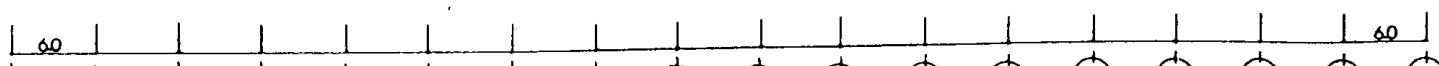
(1) (2) (3) (4) (5) (6) (7) (8) (9) (10) (19) (12) (13) (14) (15) (16) (19) (18)

図 1 建物 F の基準階梁伏困 


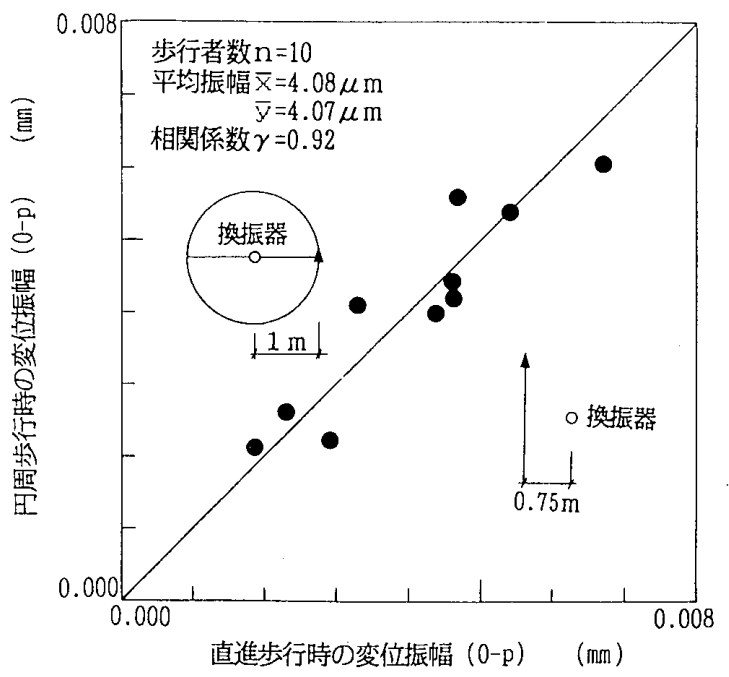

図 2 円周歩行と直進歩行の対応

表 1 歩行時振動の変位振幅のばらつき

\begin{tabular}{|c|c|c|c|c|c|c|}
\hline \multirow{2}{*}{$\begin{array}{l}\text { 歩 } \\
\text { 行 } \\
\text { 者 } \\
\end{array}$} & \multirow{2}{*}{$\begin{array}{l}\text { 性 } \\
\text { 別 }\end{array}$} & \multirow{2}{*}{$\begin{array}{l}\text { 体 } \\
\text { 重 } \\
\mathrm{Kg} \\
\end{array}$} & \multirow{2}{*}{$\begin{array}{c}\text { 変動 } \\
\text { 係数 } \\
\% \\
\end{array}$} & \multicolumn{2}{|c|}{$\frac{\delta_{\text {Max }} \text { Pin }}{P(\sigma) \text { 平均值 }}$} & \multirow{2}{*}{ 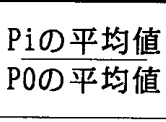 } \\
\hline & & & & $\operatorname{Max}$ & Min & \\
\hline $\begin{array}{l}\text { P0 } \\
\text { 并野 }\end{array}$ & $\mathrm{M}$ & 65 & 27.5 & 1.6 & 0.6 & 1.0 \\
\hline $\mathrm{P} 1$ & $\mathrm{M}$ & 56 & 14.8 & 1.5 & 0.5 & 1.5 \\
\hline P2 & M & 74 & 12.5 & 1.4 & 0.6 & 1.4 \\
\hline P3 & M & 64 & 38.9 & 1.8 & 0.4 & 1.3 \\
\hline P4 & M & 71 & 13.6 & 1.6 & 0.6 & 1.1 \\
\hline P5 & M & 59 & 19.0 & 1.8 & 0.5 & 1.1 \\
\hline P6 & $\mathrm{F}$ & 52 & 17.5 & 1.7 & 1.6 & 1.0 \\
\hline P7 & $\mathrm{M}$ & 62 & 15.4 & 1.8 & 0.5 & 0.7 \\
\hline P8 & $\mathrm{F}$ & 48 & 18.2 & 1.5 & 0.5 & 0.6 \\
\hline $\mathrm{Pg}$ & $F$ & 61 & 19.0 & 1.7 & 0.4 & 0.5 \\
\hline
\end{tabular}

8〜 1.4倍であり、井野の平均振幅を基準とした場合の他 の歩行者の平均振幅は $1.5 \sim 0.5$ 倍である。

\section{4. 歩行時変位振幅の推定法}

\section{1 歩行時変位振幅と 1 次固有振動数の関係}

文献 2 )に記載の大たわみ障害の生じた $\mathrm{R} C$ 床スラブ の実測データについて、縦軸に歩行時の変位振幅 $\delta_{d}$ を とり、横軸に 1 次固有振動数 $\mathrm{f}$ 、をとって散布図を描く と、両者の間には図 3 に示すような関係がられる。

これは、2 直線 $\mathrm{f}_{\mathrm{v}}=\mathrm{a} 、 \delta_{\mathrm{d}}=\mathrm{b}$ を渐近線とする直角 双曲線で、この関係式は次のようにして導かれる6)。す なわち、図4のように縦軸に変位振幅 $\delta$ a、横軸に変位 振幅の振動数に対する比 $\delta a / \mathrm{f}_{\mathrm{v}}$ をとり、座標上にプロ ットすると両者の間には次の直線関係が得られる。

$$
\delta_{\mathrm{a}}=\mathrm{b}+\mathrm{a} \frac{\delta_{\mathrm{a}}}{\mathrm{f}_{\mathrm{v}}}
$$

いま、図4にプロットした実測テータから、（1）式 の䋆数 $\mathrm{a}$ と $\mathrm{b}$ を最小自乗法で求めると次の值を得る。

$$
\mathrm{a}=7.1357, \quad \mathrm{~b}=0.0059
$$

したがって、（1）式は

$$
\delta_{\mathrm{d}}=0.0059+7.1357 \frac{\delta_{\mathrm{d}}}{\mathrm{f}_{\mathrm{v}}}
$$

となる。ここで、（2）式の上下に信頼度 $99 \%$ の限界線 を引くと、○印で示した 1 点がこの外側に出ることから、 この点を異常値とみなし、これを除いて係数 $\mathrm{a} 、 \mathrm{~b}$ を再 計算すると

$$
a=7.3940 、 \quad b=0.0055
$$

となり、直線の式は

$$
\delta_{\mathrm{d}}=0.0055+7.3940 \frac{\delta_{\mathrm{a}}}{\mathrm{f}_{\mathrm{v}}}
$$

となる。これより、図3の関係を満たす曲線は次の式と して求められる。

$$
\delta_{d}=0.0055+\frac{0.0407}{f_{v}-7.3940}
$$

（4）式を図 3 の散布図上に併記すると比較的よく適 合していることが分かる。

各建物ことに床スラブの歩行時の変位振幅と振動数の

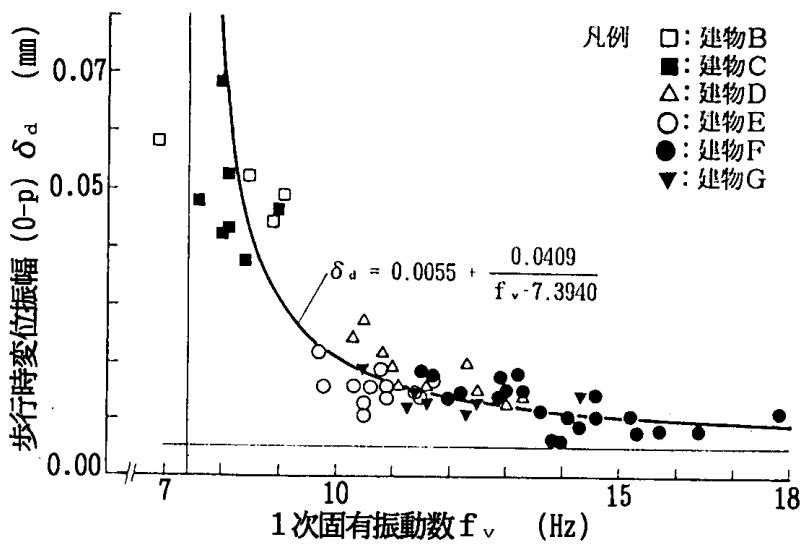

図3 歩行時変位振幅 $\delta_{\mathrm{d}}$ と 1 次固有振動数 $\mathrm{f}_{\text {v }}$ との関係

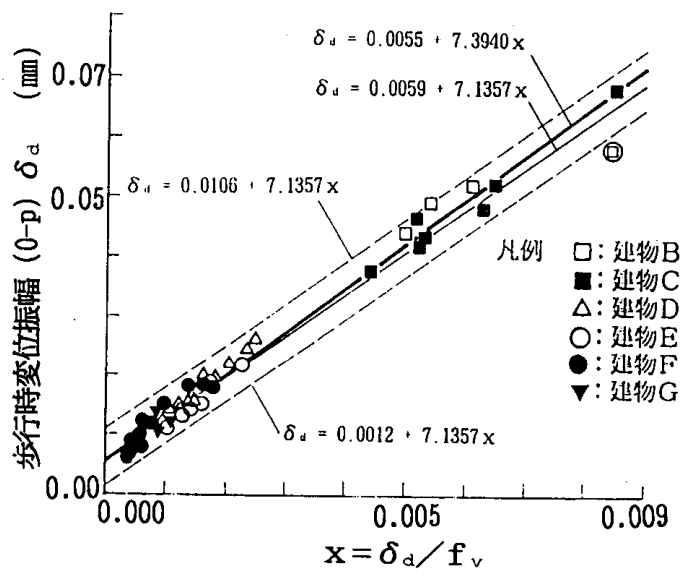

図 4 歩行時変位振幅 $\delta_{\mathrm{d}}$ と歩行時変位振幅の 1 次固有振動数 に対する比 $\delta_{\mathrm{a}} / \mathrm{f}_{\mathrm{v}}$ との関係 

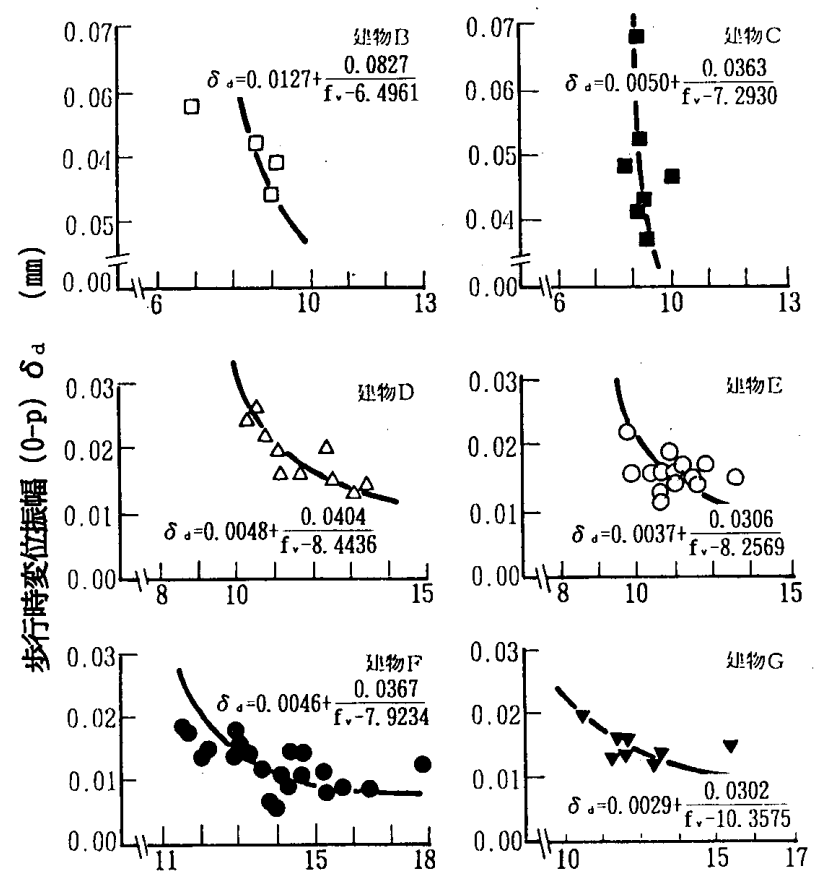

1 次固有振動数 $\mathrm{f}$ 、

(Hz)

図5各建物ことの步行時変位振幅と振動数の関係

関係式を推定すると図 5 のようになる。床スラブのたわ み障害の程度に応じて、双曲線関数の係数に若干の差異 が認められるものの、これは各建物の調查データ数が少 ないために生じているもので、有意の差とはなっていな い。したがって、本報では $\delta$ d $\mathrm{f}$ 、関係をたわみの大 きさとは無関係な 1 本の式として (4) 式を提案するも のである。

\section{2 適合性の検討}

文献 2 ) に揭げた R C 床スラブの 1 次固有振動数の実 湘值を用いて、歩行時変位振幅の推定值を（4）式より 算出し、それに変位振幅の実測值を対岕させプロットす ると図6のようになる。障害の程度の特に甚だしい建物 B (住宅)とC (事務所) を除いては、全体的に比較的 よい対応がみられるが、この両者については、ばらつき が大きく適合性はそれ程よいようには見受けられない。 これは図 3 から明らかなように、点は曲線の回りにばら ついているが、縦軸の漸近線の付近にあるために、実測 值と推定值との偏差が大きく現れるためである。

図 7 に、歩行時変位振幅における奏測值の推定值に対 する誤差率の頻度分布を示した。図中に併記した曲線か らも明らかなように、全体（実線）では、平均値 $0.00 、$ 標準偏差 0.284 となり、ばらつきがやや大きいが、建物 $\mathrm{B}$ と C 除くと（破線）平均值 0.00 、標準偏差0.218 と なり全体の約 $70 \%$ ののが図 6 の点線内の $\pm 20 \%$ に 納まる。したがって、（4）式は振動数と変位振幅との 関係を十分満たしている関数といえよう。 4.3 健全な床スラブへの適合性の検討

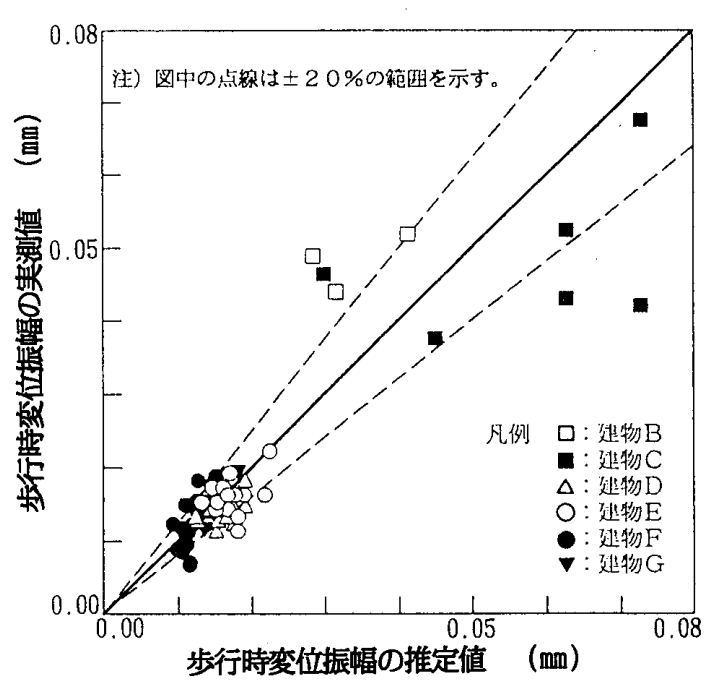

図6 步行時変位振幅の実測值と推定值の対応

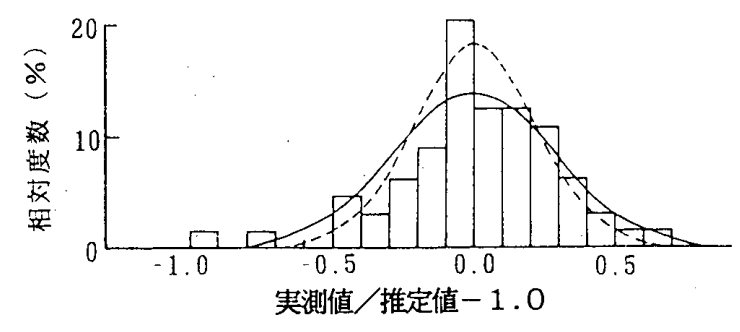

図7 歩行時変位振幅における実測値の推定値に 対する誤差率の頻度分布

ある外乱によって励起される床スラブ振動の振動数お よび振幅は、ともに板剛度、スパン、重量、減衰定数を 共通の変数とする力学的举動である。（4）式は、たわ み障害をもつ 1 次固有振動数が $7.4 \sim 17.8 \mathrm{H} \mathrm{z}$ の範囲の 床スラフの実測データを分析して導かれたものであるが、 検討対象には比較的健全な床スラフも含まれており、ス パン、スラフ厚、積載荷重、振動数、減衰定数などが、 本分析に用いたデータとの間に大きな隔たりがない場合 には、（4）式を健全な床スラブへ適用することもでき るように思われる。

表 3 は、健全な床スラフ 17 枚の歩行時変位振幅の実 測値と（4）式による推定值を比較したものである。内 訳は本報で取り上げた建物 $\mathrm{G}$ の增築部における平板 2 枚 と、 $\mathrm{K} 、 \mathrm{~L}$ 建物のスラブ中央に十字の厚肉部をもつ田型 変厚板 4 枚、およびM建物のドロップハンチ付きの回型 変厚板 11 枚で、いずれも大梁間を 1 パネルとする大た わみなどの見られない床スラブである。これらの健全な 床スラブの歩行時変位実測振幅に対する推定値は、平均 比率が1.05、標準偏差は0.16となっており、実用上十分 な精度で芯答変位を推定している。

（4）式の基礎データである障害スラフと、同式の適 用性の可否を検討した健全スラブの構造諸元と振動性状 
は、表 4 に示す通りである。これら を包括する以下の条件、すなわち、 (1)床面積か5 $50 \mathrm{~m}$ 以下、(2)スラブ厚 (変厚板にあっては平均スラフ厚) が $180 \mathrm{~m} \mathrm{~m}$ 以下、(3積載荷重が設 計值の $1 / 3$ 以下、(4) 1 次振動数 $8 \sim 20 \mathrm{~Hz}$ 、(5)減衰定数が $0.02 \sim$ 0.07、をみたし大梁間が 1 パネルか らなるR C床スラフを（4）式の適 用範囲とする。

一般に、固有振動数が $20 \mathrm{H} \mathrm{z}$ 以 上あるような通常の R C 床スラフで は、不快な有感振動に対する苦情は

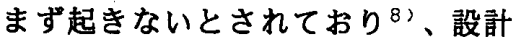
時に振動感覚評価が必要となるよう な床スラブで上の諸条件をみたすも のに限り、その煡全度に関係なく歩 行時振幅の推定に（4) 式を適応し ても大きな誤差は生しないと考える。 なお、振動数が $25 \mathrm{H} \mathrm{z}$ 以上とな る床スラブ、とくに小梁付き床スラ ブについては、歩行時振幅が $5 \mu \mathrm{m}$ 内外となること多く9)、これらの範 囲についての（4）式による予測值 は、必ずしも罗当な数値を与えると はいえない。20 H z を越える床ス ラフに関しては、より詳細な検討を 行ない稿を改めて報告する予定であ る。

\section{5. 歩行時の振動感覚評価}

\section{1 試験方法}

スラブ中央に設置した換振器を中 心として、半径約 $1 \mathrm{~m}$ の円周上を、 大人が普通の状態で歩行したときの 振動を記録する。次に、換振器を取 り除き、スラフ中央に 1 人、対角線 上のスラフ中央から約 $1.5 \mathrm{~m}$ 離れた 箇所に4人がそれそれ椅子に座り、 位㯰と方向を図 8 に揭げる 4 通りに とり、円周歩行時とほほ同じ状態で 2 回ずつ直進歩行したときの振動感 賞を、表 5 に揭ける基準により 5 段 階評価した。ちなみに、換振器で測 定した円周歩行時の振動と被験者の 感じた直進歩行時の振動の再現性に ついては、3章の検討結果に基づき、
表 3 健全な床スラブに対する (4) 式の適合性の唡討

\begin{tabular}{|c|c|c|c|c|c|c|c|}
\hline 建 & & 梁心スパン & $\begin{array}{ll}\text { 設 } & \text { 計 }\end{array}$ & 実 測 & 步行時 & 位振幅 & 比 率 \\
\hline $\begin{array}{l}\text { 物 } \\
\text { 名 }\end{array}$ & 種. 類 & $\begin{array}{ll}\mathrm{Lx} \times \mathrm{Ly} \\
\mathrm{m} & \mathrm{m} \\
\end{array}$ & $\begin{array}{c}\text { スラブ厚 } \\
\mathrm{mm}\end{array}$ & $\begin{array}{c}\text { 振動数 } \\
\mathrm{Hz}\end{array}$ & $\begin{array}{c}\text { (1)実測 } \\
\mu\end{array}$ & $\begin{array}{c}\text { (2) 推定 } \\
\mu\end{array}$ & (2) $/$ (1) \\
\hline G & $\begin{array}{l}\text { 平 板 } \\
\text { (モル夕ル) }\end{array}$ & $4.50 \times 7.00$ & $\begin{array}{l}148^{*} \\
151^{*}\end{array}$ & 17.4 & 10.4 & 9.6 & 0.92 \\
\hline K & $\begin{array}{l}\text { 田 型 } \\
\text { 変厚板 }\end{array}$ & $6.90 \times 7.50$ & $130 / 260$ & $\begin{array}{l}20.3 \\
15.7\end{array}$ & $\begin{array}{l}8.1 \\
8.7\end{array}$ & $\begin{array}{r}8.7 \\
10.4\end{array}$ & $\begin{array}{l}1.07 \\
1.20\end{array}$ \\
\hline $\mathrm{L}$ & $\begin{array}{l}\text { 田 型 } \\
\text { 変厚板 }\end{array}$ & $7.00 \times 7.00$ & $129^{*} / 250^{*}$ & 13.9 & 11.2 & 11.8 & 1.05 \\
\hline & $\begin{array}{l}\text { 同 上 } \\
\text { (モルタル) }\end{array}$ & 11 & נו & 13.8 & 12.1 & 11.9 & 0.99 \\
\hline $\mathrm{M}$ & $\begin{array}{l}\text { 回 型 } \\
\text { 変厚板 } \\
\text { (モル夕ル) }\end{array}$ & $6.20 \times 6.40$ & $140 / 215$ & $\begin{array}{l}23.4 \\
20.2 \\
21.2 \\
21.3 \\
20.1 \\
23.4 \\
19.5 \\
22.8 \\
25.0 \\
21.4 \\
21.4\end{array}$ & $\begin{array}{r}5.9 \\
8.4 \\
7.5 \\
7.5 \\
10.0 \\
7.5 \\
9.2 \\
6.5 \\
7.3 \\
8.0 \\
9.0 \\
\end{array}$ & $\begin{array}{l}8.0 \\
8.7 \\
8.5 \\
8.4 \\
8.7 \\
8.0 \\
8.9 \\
8.1 \\
7.8 \\
8.4 \\
8.4\end{array}$ & $\begin{array}{l}1.36 \\
1.04 \\
1.13 \\
1.12 \\
0.87 \\
1.07 \\
0.97 \\
1.25 \\
1.07 \\
1.05 \\
0.93\end{array}$ \\
\hline
\end{tabular}

* : 実測スラブ厚、特記外は直仕上げ

表 4 振動数と歩行時振幅の関係式 (4) をみたす床スラフ一覧

\begin{tabular}{|c|c|c|c|c|c|c|c|c|c|c|c|}
\hline \multirow{2}{*}{$\begin{array}{l}\text { 健 } \\
\text { 全 } \\
\text { 度 }\end{array}$} & \multirow{2}{*}{$\begin{array}{l}\text { 建 } \\
\text { 物 } \\
\text { 名 }\end{array}$} & \multirow{2}{*}{$\begin{array}{l}\text { 種 } \\
\text { 類 }\end{array}$} & \multirow{2}{*}{$\begin{array}{c}\text { 短 辺 } \\
\text { スパン } \\
\mathrm{m}\end{array}$} & \multirow[t]{2}{*}{ 辺艮比 } & \multicolumn{2}{|c|}{$\begin{array}{c}\text { スラプ厚 } \\
\mathrm{m} \mathrm{m}\end{array}$} & \multirow{2}{*}{$\begin{array}{l}\text { 実積載 } \\
\text { 荷 重 } \\
\mathrm{kg} / \mathrm{cm}^{2}\end{array}$} & \multicolumn{2}{|c|}{$\begin{array}{c}1 \text { 次振動数 } \\
\mathrm{H} \mathrm{z}\end{array}$} & \multicolumn{2}{|c|}{$\begin{array}{r}\text { 減衰定数 } \\
10^{-2}\end{array}$} \\
\hline & & & & & $\overline{\bar{x}}$ & $\mathrm{~s}$ & & $\bar{x}$ & $\mathbf{s}$ & $\bar{x}$ & $\mathbf{s}$ \\
\hline \multirow{10}{*}{$\begin{array}{l}\text { 大 } \\
\text { た } \\
\text { わ } \\
\text { み } \\
\text { 障 } \\
\text { 害 }\end{array}$} & A & 平板 & 7.30 & 1.00 & 165 & 12.6 & $0 \sim 100$ & 6.7 & 1.01 & 3.1 & 0.65 \\
\hline & B & II & 6.00 & 1.08 & 135 & 16.0 & 0 & 8.6 & 1.03 & - & - \\
\hline & C & 11 & 5.40 & 1.11 & 129 & 7.6 & $0 \sim 100$ & 8.2 & 0.43 & 3.5 & 0.97 \\
\hline & D & II & 6.00 & 1.00 & $150^{*}$ & & $0 \sim 60$ & 12.2 & 1.62 & 4.6 & 1.52 \\
\hline & $\mathrm{E}$ & "I & 5.85 & 1.23 & $150^{*}$ & & $0 \sim 100$ & 10.9 & 0.75 & 4.8 & 1.72 \\
\hline & $\mathrm{F} 1$ & "I & 6.00 & 1.13 & 155 & 9.5 & $0 \sim 103$ & 13.6 & 1.24 & 3.2 & 1.67 \\
\hline & $\mathrm{F} 2$ & 11 & 5.60 & 1.07 & 161 & 8.1 & $55 \sim 80$ & 16.3 & 1.34 & 4.9 & 2.98 \\
\hline & G1 & II & 4.50 & 1.56 & 128 & 12.0 & $0 \sim 50$ & 12.0 & 1.19 & 2.9 & 0.34 \\
\hline & G2 & "I & 4.75 & 1.47 & $120^{*}$ & & 50 & 11.3 & - & 2.6 & - \\
\hline & $\mathrm{H}$ & II & 4.25 & 1.65 & $135^{*}$ & & $0 \sim 50$ & 13.4 & 2.11 & 4.0 & 1.41 \\
\hline \multirow{3}{*}{ 健 } & G & 平板 & 4.50 & 1.56 & 149 & 27.4 & 50 & 18.5 & 1.56 & 3.4 & 0.25 \\
\hline & $\mathrm{K} 1$ & 田型 & 6.90 & 1.09 & $170^{*}$ & & 0 & 20.3 & - & 2.2 & - \\
\hline & K2 & "I & 6.90 & 1.09 & $170^{*}$ & & 0 & 15.7 & - & 5.3 & - \\
\hline & L1 & II & 7.00 & 1.00 & $170^{*}$ & & 0 & 13.9 & 0.28 & 6.7 & 2.28 \\
\hline \multirow[t]{2}{*}{ 全 } & L2 & נו & 7.00 & 1.00 & $170^{*}$ & & 60 & 13.8 & 0.66 & 5.8 & 1.63 \\
\hline & M & 回型 & 6.20 & 1.03 & $170^{*}$ & & $0 \sim 50$ & 21.8 & 1.67 & 3.6 & 0.66 \\
\hline
\end{tabular}

*: 設計スラプ厚、田型・回型変厚板 (* : 平均設計スラフ厚)、 $\bar{x}:$ 平均値 $\mathbf{s}:$ 標準偏差、実糟载荷重 : 推定值、振動数-減衰定数: 平均実測值

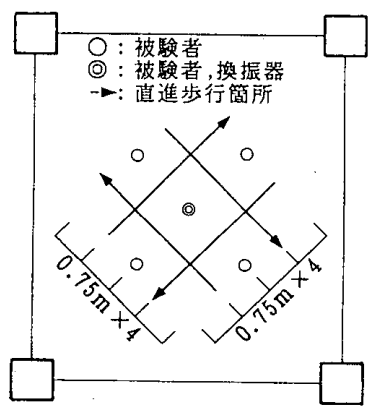

\begin{tabular}{c|l} 
表 5 & \multicolumn{1}{|c}{ 振動感覚の評価基準 } \\
\hline 評点 & \multicolumn{1}{|c}{ 評価基準 } \\
\hline 5 & 強く感じる \\
4 & よく感じる \\
3 & 感じる \\
2 & かすかに感じる \\
1 & ほとんと感じない \\
\hline
\end{tabular}

図 8 振動感賞試験における 換振器と歩行箇所 
表 6 歩行時振動の感覚評価試験結果一覧

\begin{tabular}{|c|c|c|c|c|c|}
\hline 階 & 位 置 & $\begin{array}{c}\text { 振動数 } \\
\mathrm{H} \mathrm{z}\end{array}$ & $\begin{array}{c}\text { たわみ } \\
\mathrm{mm}\end{array}$ & $\begin{array}{c}\text { 半振幅 } \\
\mu \mathrm{m}\end{array}$ & $\begin{array}{l}\text { 振 動 } \\
\text { 感 覚 }\end{array}$ \\
\hline \multirow[t]{20}{*}{1} & $1-B$ & 17.7 & 23.5 & 14.6 & 3.4 \\
\hline & $1-C$ & 14.3 & 36.5 & 20.0 & 3.6 \\
\hline & $2-A$ & 18.5 & 28.5 & 6.2 & 2.2 \\
\hline & $5-A$ & 13.4 & 23.5 & 15.6 & 3.0 \\
\hline & $9-B$ & 15.6 & 15.5 & 11.0 & 3.4 \\
\hline & $12-\mathrm{A}$ & 15.0 & 20.5 & 15.6 & 3.0 \\
\hline & $13-A$ & 14.1 & 27.5 & 17.5 & 3.2 \\
\hline & $13-B$ & 18.6 & 21.0 & 11.2 & 3.2 \\
\hline & $13-\mathrm{C}$ & 13.9 & 27.5 & 21.5 & 4.0 \\
\hline & $14-A$ & 16.2 & 22.5 & 12.2 & 3.0 \\
\hline & $14-8$ & 18.4 & 18.0 & 10.4 & 2.8 \\
\hline & $14-C$ & 15.9 & 16.0 & 12.5 & 3.2 \\
\hline & $15-\AA$ & 14.6 & 25.5 & 14.8 & 3.2 \\
\hline & $15-B$ & 33.0 & 11.5 & 2.3 & 1.6 \\
\hline & $15-C$ & 23.2 & 13.5 & 4.1 & 3.0 \\
\hline & $16-A$ & 15.4 & 29.0 & 15.6 & 2.8 \\
\hline & $16-B$ & 33.3 & 13.5 & 2.5 & 1.8 \\
\hline & $16-\mathrm{C}$ & 26.9 & 11.5 & 2.2 & 1.6 \\
\hline & $17-C$ & 19.5 & 8.0 & 7.3 & 2.0 \\
\hline & $17-0$ & 17.3 & 10.8 & 9.7 & 2.4 \\
\hline \multirow[t]{19}{*}{2} & 4-A & 14.8 & 27.5 & 14.1 & 2.8 \\
\hline & $5-A$ & 12.7 & 38.0 & 19.8 & 3.2 \\
\hline & $9-\mathrm{C}$ & 13.8 & 23.5 & 15.1 & 2.4 \\
\hline & $11-A$ & 15.3 & 20.0 & 16.7 & 3.4 \\
\hline & $13-C$ & 13.9 & 31.0 & 15.7 & 3.2 \\
\hline & $15-B$ & 14.1 & 24.5 & 21.1 & 3.4 \\
\hline & $15-\mathrm{C}$ & 11.6 & 29.5 & 24.1 & 3.6 \\
\hline & $16-A$ & 13.0 & 29.8 & 18.3 & 3.6 \\
\hline & $16-B$ & 15.3 & 26.5 & 14.3 & 3.4 \\
\hline & $16-C$ & 12.7 & 36.8 & 22.6 & 3.0 \\
\hline & $16-D$ & 13.2 & 31.3 & 15.5 & 3.4 \\
\hline & 17-D & 12.5 & 30.3 & 21.9 & 3.4 \\
\hline & $1-F$ & 14.1 & 26.0 & 16.3 & 2.6 \\
\hline & $1-G$ & 14.9 & 14.5 & 12.1 & 2.4 \\
\hline & $2 \cdot F$ & 13.2 & 23.5 & 20.1 & 3.0 \\
\hline & $2-G$ & 14.2 & 28.0 & 10.4 & 2.2 \\
\hline & $3-E$ & 15.3 & 26.5 & 11.5 & 2.2 \\
\hline & 3-F & 14.2 & 26.0 & 16.6 & 1.8 \\
\hline & $3-G$ & 15.5 & 18.0 & 12.4 & 2.0 \\
\hline \multirow[t]{11}{*}{3} & $1-\bar{A}$ & 15.7 & 21.0 & 18.9 & 2.6 \\
\hline & $1-B$ & 16.4 & 19.5 & 18.9 & 2.8 \\
\hline & $1-C$ & 21.4 & 14.5 & 6.0 & 1.8 \\
\hline & $5-A$ & 13.8 & 24.5 & 31.3 & 2.4 \\
\hline & $5-C$ & 14.2 & 23.5 & 23.9 & 2.6 \\
\hline & $6-C$ & 14.1 & 21.5 & 15.0 & 2.8 \\
\hline & $7-C$ & 14.8 & 22.0 & 15.9 & 2.2 \\
\hline & $9-\mathrm{C}$ & 14.0 & 25.0 & 13.0 & 2.6 \\
\hline & $11-\mathrm{A}$ & 13.3 & 18.0 & 17.2 & 3.2 \\
\hline & $12-\mathrm{A}$ & 13.2 & 14.5 & 29.1 & 2.8 \\
\hline & $13-\mathrm{C}$ & 13.2 & 6.0 & 24.7 & 3.2 \\
\hline
\end{tabular}

\begin{tabular}{|c|c|c|c|c|c|}
\hline 階 & 位 置 & $\begin{array}{c}\text { 振動数 } \\
\mathrm{H}_{2}\end{array}$ & $\begin{array}{c}\text { たわみ } \\
\mathrm{mm}\end{array}$ & $\begin{array}{c}\text { 半振幅 } \\
\mu \mathrm{m}\end{array}$ & $\begin{array}{ll}\text { 振 } & \text { 動 } \\
\text { 感 覚 }\end{array}$ \\
\hline \multirow[t]{16}{*}{3} & $14 \cdot \mathrm{C}$ & 14.6 & 5.0 & 16.1 & 2.6 \\
\hline & $15-A$ & 13.3 & 15.0 & 22.2 & 3.2 \\
\hline & $15-B$ & 15.0 & 8.0 & 18.9 & 3.2 \\
\hline & $15-C$ & 13.0 & 15.5 & 18.3 & 3.4 \\
\hline & $16-\mathrm{A}$ & 13.5 & 19.0 & 18.4 & 3.0 \\
\hline & $16-B$ & 16.4 & 16.5 & 10.3 & 2.8 \\
\hline & $16-0$ & 11.5 & $29.0^{\circ}$ & 29.1 & 3.6 \\
\hline & $17-B$ & 15.8 & 15.0 & 14.7 & 3.2 \\
\hline & $17-0$ & 12.0 & 29.0 & 17.5 & 3.0 \\
\hline & $1-E$ & 14.8 & 20.5 & 16.2 & 3.0 \\
\hline & $1-F$ & 13.1 & 35.0 & 20.4 & 3.0 \\
\hline & $1-G$ & 12.6 & 29.0 & 25.9 & 3.2 \\
\hline & $2-F$ & 12.4 & 29.5 & 20.4 & 2.8 \\
\hline & $2-G$ & 14.0 & 22.5 & 19.6 & 2.8 \\
\hline & $3-F$ & 13.1 & 23.0 & 16.6 & 3.2 \\
\hline & $3-G$ & 11.9 & 39.5 & 21.0 & 3.4 \\
\hline \multirow[t]{32}{*}{4} & $1-A$ & 12.9 & 28.0 & 16.9 & 2.4 \\
\hline & $1-B$ & 15.5 & 21.5 & 13.4 & 2.8 \\
\hline & $1-C$ & 13.7 & 29.5 & 23.8 & 3.2 \\
\hline & $4-A$ & 13.6 & 23.0 & 14.0 & 2.6 \\
\hline & $5-A$ & 12.3 & 17.0 & 13.7 & 3.0 \\
\hline & $5-C$ & 12.7 & 21.0 & 26.8 & 2.6 \\
\hline & $6-A$ & 13.1 & 25.0 & 17.1 & 2.6 \\
\hline & $6-c$ & 12.1 & 22.5 & 24.4 & 3.2 \\
\hline & 7-C & 13.9 & 28.0 & 18.3 & 3.2 \\
\hline & $9 \cdot C$ & 13.1 & 28.0 & 14.9 & 2.2 \\
\hline & $12-A$ & 12.4 & 25.0 & 21.1 & 3.2 \\
\hline & $13 \cdot A$ & 12.0 & 37.5 & 22.1 & 3.2 \\
\hline & $13-C$ & 12.6 & 32.0 & 18.9 & 3.6 \\
\hline & $14-A$ & 12.0 & 29.0 & 22.9 & 3.0 \\
\hline & $14-C$ & 11.6 & 32.0 & 28.3 & 3.4 \\
\hline & $15-B$ & 14.8 & 23.0 & 15.3 & 2.8 \\
\hline & $15-\mathrm{C}$ & 12.2 & 34.5 & 22.5 & 3.2 \\
\hline & $15-0$ & 12.5 & 24.0 & 18.8 & 3.0 \\
\hline & $16-\mathrm{A}$ & 12.4 & 32.0 & 26.9 & 3.2 \\
\hline & $16-8$ & 14.2 & 27.5 & 18.1 & 3.4 \\
\hline & $16-C$ & 12.6 & 36.0 & 19.7 & 3.0 \\
\hline & $16-0$ & 11.3 & 30.0 & 29.7 & 4.0 \\
\hline & $17-\mathrm{A}$ & 11.4 & 27.5 & 25.6 & 3.8 \\
\hline & $17-8$ & 13.9 & 30.0 & 21.0 & 3.6 \\
\hline & $17-C$ & 12.4 & 33.0 & 22.3 & 3.2 \\
\hline & $17-0$ & 10.7 & 37.5 & 30.4 & 3.6 \\
\hline & $1-F$ & 13.3 & 27.0 & 14.1 & 2.8 \\
\hline & $1-G$ & 14.0 & 24.5 & 15.4 & 2.4 \\
\hline & $2 \cdot F$ & 13.3 & 27.5 & 16.5 & 2.6 \\
\hline & $2-G$ & 14.3 & 22.5 & 13.1 & 1.8 \\
\hline & $3-F$ & 12.4 & 34.5 & 17.4 & 2.6 \\
\hline & $3-G$ & 12.6 & 28.5 & 21.7 & 2.4 \\
\hline \multirow[t]{2}{*}{5} & $1-A$ & 14.1 & 23.5 & 19.3 & 2.4 \\
\hline & $1-B$ & 17.4 & 17.0 & 12.0 & 2.4 \\
\hline
\end{tabular}

\begin{tabular}{|c|c|c|c|c|c|}
\hline 階 & 位 置 & $\begin{array}{c}\text { 振動数 } \\
\mathrm{H} \mathrm{z}\end{array}$ & $\begin{array}{c}\text { たわみ } \\
\mathrm{mm}\end{array}$ & $\begin{array}{c}\text { 半振幅 } \\
\mu \mathrm{m}\end{array}$ & $\begin{array}{ll}\text { 振 } & \text { 動 } \\
\text { 感 } \\
\text { 觉 }\end{array}$ \\
\hline \multirow[t]{21}{*}{5} & $2-A$ & 15.0 & 16.5 & 14.3 & 2.6 \\
\hline & $6-C$ & 14.8 & 23.5 & 16.0 & 2.4 \\
\hline & $7-c$ & 16.1 & 28.5 & 17.8 & 2.4 \\
\hline & $8+A$ & 14.3 & 14.5 & 14.1 & 2.2 \\
\hline & 3-A & 14.6 & 23.5 & 15.5 & 2.2 \\
\hline & $9-C$ & 14.3 & 23.0 & 14.9 & 2.4 \\
\hline & $13-A$ & 13.9 & 18.5 & 16.4 & 2.4 \\
\hline & $14-C$ & 15.5 & 12.5 & 12.7 & 2.2 \\
\hline & $15-A$ & 14.8 & 16.0 & 12.4 & 2.2 \\
\hline & $16-A$ & 14.2 & 19.5 & 16.4 & 2.4 \\
\hline & $16-B$ & 16.1 & 14.0 & 10.6 & 2.2 \\
\hline & $16-0$ & 14.3 & 15.5 & 14.6 & 3.0 \\
\hline & $17-8$ & 16.7 & 12.5 & 15.6 & 2.4 \\
\hline & $17-C$ & 14.1 & 17.0 & 16.1 & 3.0 \\
\hline & $17-0$ & 13.4 & 24.0 & 19.2 & 3.0 \\
\hline & $1-E$ & 15.4 & 23.0 & 16.9 & 2.8 \\
\hline & $1 \cdot F$ & 13.8 & 23.5 & 16.3 & 2.4 \\
\hline & $1-C_{A}$ & 13.9 & 22.5 & 14.4 & 3.0 \\
\hline & $2-f$ & 13.8 & 32.5 & 12.2 & 3.2 \\
\hline & $3-F$ & 13.6 & 31.5 & 15.2 & 3.2 \\
\hline & $3-G$ & 13.4 & 32.5 & 18.0 & 3.0 \\
\hline \multirow[t]{27}{*}{6} & $1-A$ & 12.5 & 34.5 & 26.3 & 3.8 \\
\hline & $1-B$ & 15.6 & 21.0 & 14.4 & 3.0 \\
\hline & $2-A$ & 12.7 & 35.5 & 20.7 & 3.6 \\
\hline & $5-A$ & 15.8 & 15.5 & 12.2 & 2.8 \\
\hline & $5 \cdot \mathrm{C}$ & 16.0 & 14.0 & 11.8 & 2.4 \\
\hline & 6-A & 16.1 & 16.0 & 8.5 & 2.0 \\
\hline & $8-A$ & 16.6 & 17.0 & 9.3 & 2.2 \\
\hline & $9-A$ & 16.3 & 13.0 & 12.6 & 2.4 \\
\hline & $9-C$ & 17.1 & 10.0 & 7.4 & 1.4 \\
\hline & $10-B$ & 18.3 & 18.0 & 11.0 & 2.0 \\
\hline & $11-A$ & 17.2 & 16.5 & 8.4 & 2.0 \\
\hline & $12-A$ & 15.3 & 17.0 & 11.8 & 2.4 \\
\hline & $13-A$ & 16.0 & 18.0 & 7.7 & 1.8 \\
\hline & $14-A$ & 16.4 & 16.5 & 10.2 & 2.6 \\
\hline & $15-\mathrm{C}$ & 15.7 & 20.0 & 8.5 & 1.4 \\
\hline & $16-B$ & 19.0 & 19.5 & 7.1 & 1.8 \\
\hline & $16-C$ & 15.6 & 18.0 & 6.8 & 2.0 \\
\hline & $16-0$ & 15.5 & 18.5 & 9.6 & 2.0 \\
\hline & $17-A$ & 14.8 & 18.5 & 14.0 & 3.2 \\
\hline & $17-B$ & 17.4 & 20.0 & 10.3 & 2.0 \\
\hline & $17-C$ & 15.6 & 12.5 & 9.7 & 2.0 \\
\hline & $17-0$ & 13.5 & 17.0 & 13.1 & 3.0 \\
\hline & $1-F$ & 15.0 & 22.5 & 16.5 & 2.2 \\
\hline & $2-F$ & 14.1 & 15.0 & 15.1 & 2.4 \\
\hline & $2-G$ & 13.9 & 15.0 & 14.1 & 2.6 \\
\hline & $3-F$ & 14.2 & 15.0 & 17.3 & 3.4 \\
\hline & $3-G$ & 14.2 & 26.0 & 16.1 & 3.2 \\
\hline
\end{tabular}

できるたけ両者が一致する位置と歩行数を採用した。

\section{2 試験結果}

表 6 は、148 枚の床スラブについて、振動記録から 読み取った振動数と歩行時の変位振幅（歩行ステップこ との最大全振幅の $1 / 2 、 2$ 周、約 25 歩分の平均値）、 および被験者 5 人による振動感覚の平均評点（以下、

「平均評点」)を示した。

振動数の平均值 $\bar{x}=14.8 \mathrm{H} \mathrm{z}$ 、標準偏差 $\mathrm{s}=3.1 \mathrm{H} \mathrm{z}$ 、 歩行時変位振幅 $\bar{x}=16.1 \mu \mathrm{m} 、 \mathrm{~s}=5.7 \mu \mathrm{m}$ に対する振

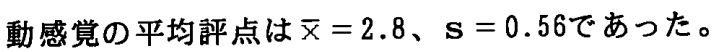

\section{3 振動感賞と振動数の関係}

振動感覚の平均評点 $\mathrm{y}$ と振動数 $\mathbf{f}$ 、をそれそれ縦軸と 横軸にとり各スラフののデータをプロットし、これを箱型 図 ${ }^{7}$ で表わすと図 9 のようになる。平均評点ことの振動 数の中央值をとり双曲線を当てはめると図 10 となる。
この曲線は図 11 に示すように、縦軸に $\mathrm{y} 、$ 横軸に $\mathrm{y} /$ $\mathbf{f}_{\mathrm{v}}$ をとり最小 2 乗法により求めた直線より導かれる。

\section{4 振動感覚と変位振幅の関係}

図 12 は、前項と同様な方法で、横軸に歩行時変位振 幅をとって描いた箱型図である。変位振幅の中央值と振 動感賞との間には図 13 に示す 1 次の指数関係が成り立 つ。これは図 14 のように振動感賞を対数にとると、変 位振幅との間に明かな直線関係が認められることから導 いたものである。

\section{5 既往の振動評価基準との比較}

感覚の平均評点が同じ領域の振動数と変位振幅を、そ れそれ図 9 および図 12 における中央值にとり、これを 日本建築学会の床振動に関する性能評価基準 ${ }^{31}$ と比較す ると図 15 のようになる。

本試験では平均評点の最低点が 2 以下、最高点がほほ 


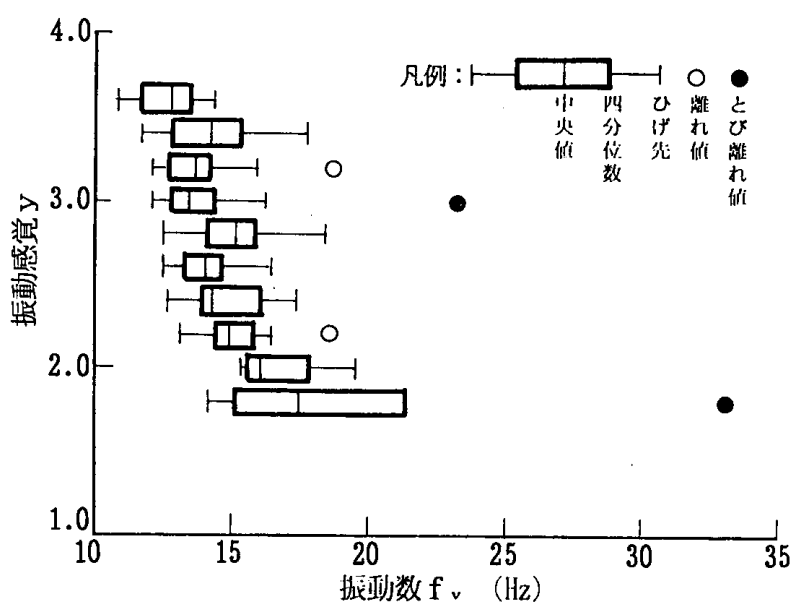

図 9 振動感覚 $y$ と振動数 $\mathrm{f}$ 、の箱型図

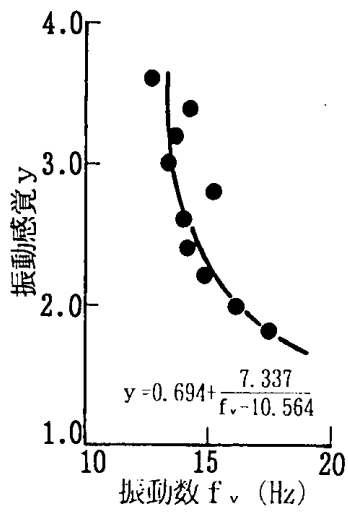

図 10 振動感覚 $y$ と振動数 $\mathrm{f} 、$ の関係

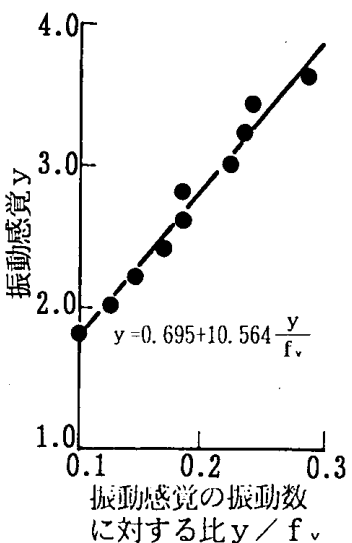

図 11 振動感賞yと振動感 賞の振動数に対する比 $\mathbf{y} / \mathbf{f}_{\mathrm{v}}$ との関係

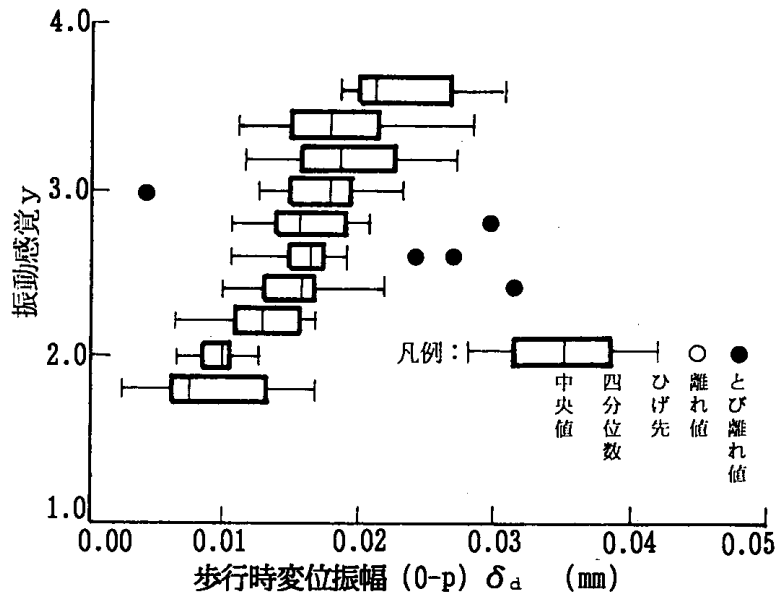

図 12 振動感覚 $\mathrm{y}$ と歩行時変位振幅 $\delta_{\mathrm{d}}$ の箱型図

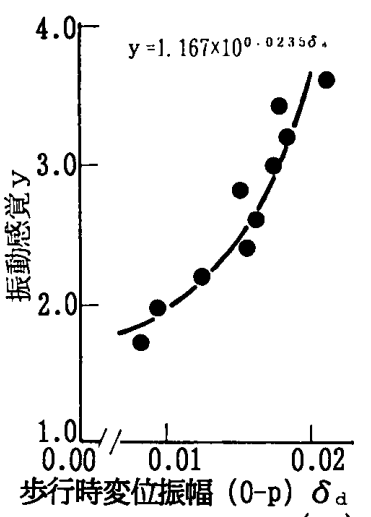

(mm)

図 13 振動感覚 $y$ と歩行時 変位振幅 $\delta_{\mathrm{d}}$ の関䋆

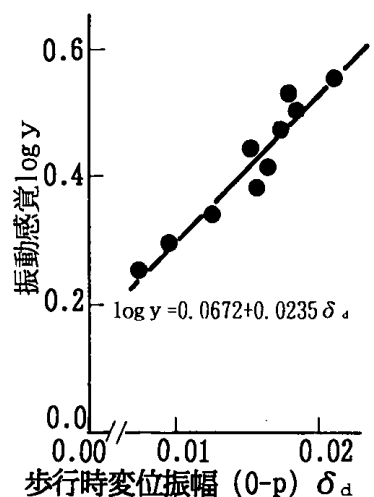

(m) 図 14 振動感賞 $\log y$ と歩行時

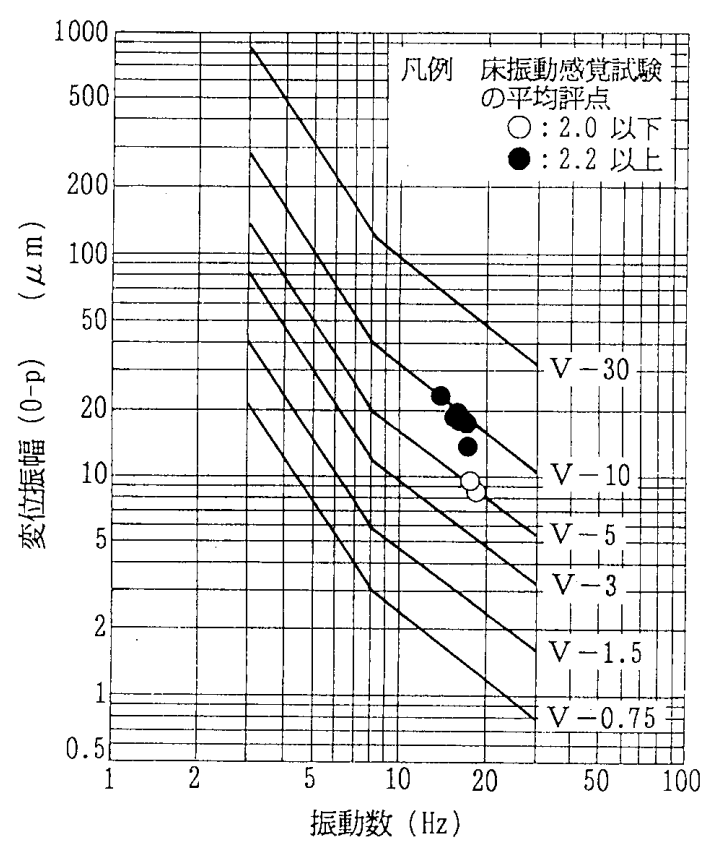

図 15 床振動に関する性能評価基準 ${ }^{33}$
4 となっている。図 15 では、評点が2「かすかに感じ る」以下はレベル V-5 を若干下回っている。 V- 5 は、 上記性能評価の用途別区分基準の一つで、振動種別を I 、 ランクをIII とした場合の事務所建築の一般事務室または 会議・応接室における上限レベルに相当している。

本試験は、建物の使用者に歩行による振動を感じさせ ない振動数と変位振幅の限界值を求める一方法を提示し たものであるが、一応、既往の評価基準に近い結果が得 られており、振動種別、用途、規模などの異なる他の試 験を積み重ねることで、より信頼性の高い振動感賞レベ ルの設定ができるように思われる。

\section{6 。をとめ}

本報は、振動数が $20 \mathrm{~Hz}$ 以下の大梁間を 1 パネルと する床スラブについて、実測データを精查・分析し、そ こから得られた知見を基にコンクリートのひび割れや時 間依存性を勘案した床スラプの歩行時変位振幅を簡便に 予測する方法の提案を試みたもので、その要約を以下に 
列挙する。

1）損傷床スラフにおける歩行時振動の変位振幅と 1 次固有振動数の間に強い相関関係があることを明ら かにし、両者の関係をみたす回帰式を導いた。

2）この回㷌式は、大梁間を 1 パネルとする健全な床 スラフについても実用上十分な精度で歩行時振動の 変位振幅を推定し得ることを示した。

3）本法による歩行時振幅予測值は、大人が普通に歩 行した時の床振動応答值であり、歩行者の違いによ って本予湘值が1.5〜0.5倍程度ばらつくことを追試 験で明らかにした。

4）床振動感賞とその評洒尺度である振動数または振 棏との関係を検討した。

本研究では、床振動の振動感賞尺度の一つである減衰 定数について触れていない。床振動感覚の他の尺度であ る振動数や振幅に関する推定方法の適用範囲を $20 \mathrm{H} \mathrm{z}$ 以上の領域、特に小梁付き床スラブへの执張と併せて今 後の課題としたい。

\section{参考文献}

1）日本建築学会 : 鉄筋コンクリート構造計算規準・同解説、 pp. 480-489, 499-516, 1988

2）伊藤正義、井野智、杉野目章、佐藤 尚 : 鉄筋コンクリ 一ト床スラブの 1 次固有周期推定法、日本建築学会構造系 論文報告集 No.457,揭載決定、1994.3

3）日本建築学会 : 建築物の振動に関する居住性能評価指針 · 同解説、P.1, 1991.4

4）杉野目章、井野 智、伊藤正義：ある多層 R C 事務所建築 の床構造についての総合的実測調查、日本建筑学会構造系 論文報告集 №.429,pp.101-110,1991.11

5）井野 智: 鉄筋コンクリート床スラフの振動性状について、 日本建築学会論文報告集 No.273,pp.13-23,1978.11

6）乗松立木：数值計算法、日本電気書院 pp.92-95,1964.6

7）渡辺 洋、鉿木則夫、山田文康、大塚雄作：探索的テータ 解析入門、朝倉畫店 1985.5

8）谷 資信編著 : 構造の動的解析、技報堂出版 pp.168, 1978.2

9）中川 修、井野智、士橋由造、杉野目章 : 実在の各種床 スラフの振動計測とその評価、日本建築学会大会学術講演 梗概集（関東） pp.2053,2054,1984.10

10）既出 3)、p.2 